\title{
Metabolic profile and skin-related bioactivities of Cerioporus squamosus hydromethanolic extract
}

\author{
WAILL A. ELKHATEEB ${ }^{1}$, GHOSON M. DABA ${ }^{1, \vartheta}$, MARWA O. ELNAHAS ${ }^{1}$, PAUL W. THOMAS $^{2,3}$, \\ MAHMOUD EMAM ${ }^{4,5, \bullet \bullet}$ \\ ${ }^{1}$ Chemistry of Natural and Microbial Products Department, Pharmaceutical Industries Division, National Research Centre. Dokki, Giza, 12622, Egypt. \\ Tel. +201013241936, Fax.: +20233370931, ^email: ghoson.daba@yahoo.com \\ ${ }^{2}$ University of Stirling, Stirling, UK. \\ ${ }^{3}$ Mycorrhizal Systems Ltd., Lancashire, UK. \\ ${ }^{4}$ College of Pharmaceutical Science \& Collaborative Innovation Center of Yangtze River Delta Region Green Pharmaceuticals, Zhejiang University of \\ Technology. Hangzhou 310014, China. Tel. +201063802898, Fax.: +20233370931, ^vemail: mahmoudemamhegazy2020@gmail.com \\ ${ }^{5}$ Department of Phytochemistry and Plant Systematics, National Research Centre. 33 El Bohouth St., Dokki, Giza 12622, Egypt
}

Manuscript received: 12 July 2020. Revision accepted: 23 September 2020.

\begin{abstract}
Elkhateeb WA, Daba GM, Elnahas MO, Thomas PW, Emam M. 2020. Metabolic profile and skin-related bioactivities of Cerioporus squamosus hydromethanolic extract. Biodiversitas 21: 4732-4740. Being a functional food capable of showing nutritional as well as medicinal properties have great attention. Mushrooms have been proven as leading targets in this field. For this purpose, the edible mushroom Cerioporus squamosus was investigated in this study to evaluate the in vitro skin-related bioactivities of its hydromethanolic extract in terms of enhancing wound healing, and human skin cancer suppression capabilities. Treatment of fibroblast cells (BJ-1) with the hydromethanolic extract of this mushroom at $50 \mu \mathrm{g} / \mathrm{mL}$ enhanced cell migration rates by $71.7 \%$ after $24 \mathrm{~h}$ of exposure to the extract. Moreover, the same extract exhibited a promising impact on human skin cancer using an epidermoid carcinoma cell line (A431). The gradual increase in C. squamosus hydromethanolic extract concentration caused gradual decrease in the A431 cell viability and proliferation. Maximum effect on reducing the cell viability was obtained at a concentration of $100 \mu \mathrm{g} / \mathrm{mL}$, where cell viability was $3.7 \%$, and recorded $\mathrm{IC}_{50}$ was $52.6 \mu \mathrm{g} / \mathrm{mL}$. The metabolic profile of the extract was analyzed by GC-MS, which was performed on its silylated metabolites. Nineteen compounds were detected including sugar alcohols, amino acids, fatty and organic acids. Promising results of this mushroom extract encourage conducting further steps towards using this mushroom as a functional food showing promising bioactivities.
\end{abstract}

Keywords: GC-MS, edible mushroom, silylated metabolites, skin cancer, wound healing

\section{INTRODUCTION}

Without ignoring its functional roles in sensation and touch, the biofunctions of the largest human organ, the skin, include also protecting the body from losing excess water, and from external factors as sun, microbes. Moreover, the skin contribute principally in the process of body temperature regulation (James et al. 2011).

Skin injuries and wounds have a range of different etiologies and they should be healed as fast as possible in order to regain the lost tissues, allow the skin to continue its functions, and to continue tissue homeostasis. Wound healing and new tissue formation mechanisms are multistep complex processes that start with inflammation, then angiogenesis, followed by granulation tissue formation, reepithelialization, and extracellular matrix reconstruction (Bolla et al. 2019). After a skin injury, immune cells quickly multiply, migrate to the injured location, and initiate wound healing mechanisms. Fibroblasts are the major cells existing in skin tissue, they rupture fibrin clots, generate extracellular matrix constituents as well as collagen structures that are needed for tissue homeostasis (Bainbridge 2013). Historically, a wide range of plant species was used for their wound healing properties and, even today, wound healing pharmaceuticals which are based mainly on plants represent more than $70 \%$ of available products (Kumarasamyraja et al. 2012). Similarly, natural extracts originating from medicinal mushrooms have formed the basis of many studies, with a growing interest in identifying extracts potent as wound healing agents. Ganoderma lucidum (reishi mushroom), Handkea utriformis (synonym of Calvatia utriformis), Hericium erinaceus, Morchella esculenta, Sparassis crispa, and Agaricus blazei are among the fungi species that have previously shown promising wound healing abilities (Gupta et al. 2014; Elkhateeb et al. 2019c).

Malignant growths or tumors, resulting from uncontrolled cell division occur throughout the body and those that are specific to skin appear to be increasing, globally. Generally, there are two main types of skin cancer (melanoma and non-melanoma). Non-melanoma skin cancer is ranked as the $5^{\text {th }}$ most commonly occurring cancer, accounting for an estimated 1.04 million deaths in 2018, while melanoma skin cancer is the $19^{\text {th }}$ most commonly occurring cancer, and the incidences of nonmelanoma and melanoma skin cancers have been increasing in recent decades (WHO Fact sheet, 2018). Generally, several mushroom species have shown 
promising in vitro and in vivo abilities against cancer (Ivanova et al. 2014; Blagodatski et al. 2018; Ray et al. 2020). Very few mushrooms have been testified to have anti-skin cancer activities such as Ganoderma lucidum, and Coriolus versicolor (Chinembiri et al. 2014). G. lucidum extract has been demonstrated to have an anti-melanoma effect in vitro, and tumor-reducing activities in vivo. $G$. lucidum induces apoptosis (cancer cell death) and inhibits proliferation of skin cancer cells (Harhaji Trajković et al. 2009), while $C$. versicolor extract caused a reduction in growth of melanoma cells and tumor volume, through inhibiting cell proliferation and inducing apoptotic and necrotic cell death (Harhaji et al. 2008).

Screening for natural potent compounds that are capable of improving wound healing process and showing at the same time anti-skin cancer activity is attracting researcher's attention in modern pharmaceutical and biomedical sciences. Edible mushrooms are put under the scientific spotlight as they are already edible and can act as a source for bioactive compounds that may supplement and/or replace currently used drugs.

Cerioporus squamosus (Huds.) Quél. is a basidiomycetous edible mushroom, C. squamosus is generally known as dryad's saddle or pheasant's back mushroom and is usually existing in the northern temperate zones.

C. squamosus extracts have been evaluated for their potential biological activities and they have previously been reported to have antioxidant, wound healing, and antimicrobial activities (Zhao 2013; Fernandes et al. 2016; Mocan et al. 2018; Elkhateeb et al. 2019c). However, the anti-skin cancer activity of this promising mushroom has not been investigated before. In this study, we strive to explore the potential in vitro anti-skin cancer properties along with the wound healing potency of $C$. squamosus methanolic extract.

\section{MATERIALS AND METHODS}

\section{Sample collection, identification, and extraction}

For this study, whole fruiting bodies of Cerioporus squamosus (Huds.) Quél. (syn. Polyporus squamosus (Huds.) Fr.) were collected from the Isle of Bute, in Scotland (UK). Fruiting bodies were found growing in clusters and were readily identified as the target species, displaying a cap with the following properties: a fan-shape, broadly convex but becoming flat and shallowly depressed in older specimens. The caps were pale tan to creamy yellowish, with large and flattened, brown to blackish scales. Pores ran down the stem, whitish to creamy (white spore print), and displayed no bruising. Flesh was thick and moderately tough with a strongly mealy aroma (Figure 1). All samples were collected from the same tree host, which was a previously felled trunk of Aesculus hippocastanum (Sapindaceae). Which had become colonized with $C$. squamosus fruit bodies. Cerioporus squamosus identification was carried out using the morphological features according to Phillips (2013).

Samples were collected on the $1^{\text {st }}$ of June 2018 and were immediately sliced and dried in a commercial heated dehydrator at approximately $75^{\circ} \mathrm{C}(\mathrm{GP}-102-1,250 \mathrm{~W}$, LASER 2000, Westfalia Werkzeug company $\mathrm{GmbH} \& \mathrm{Co}$ $\mathrm{KG}$, Germany). After dehydration, samples were extracted as described previously (Elkhateeb et al. 2019d; Daba et al. 2020). Briefly, C. squamosus fruiting body pieces were placed in an Erlenmeyer flask containing $80 \%$ methanol at room temperature and kept overnight before filtering. The resulting filtered extract was concentrated at $37^{\circ} \mathrm{C}$ using a rotary evaporator. The obtained extract was stored at $4^{\circ} \mathrm{C}$ in a clean closed container until further use.
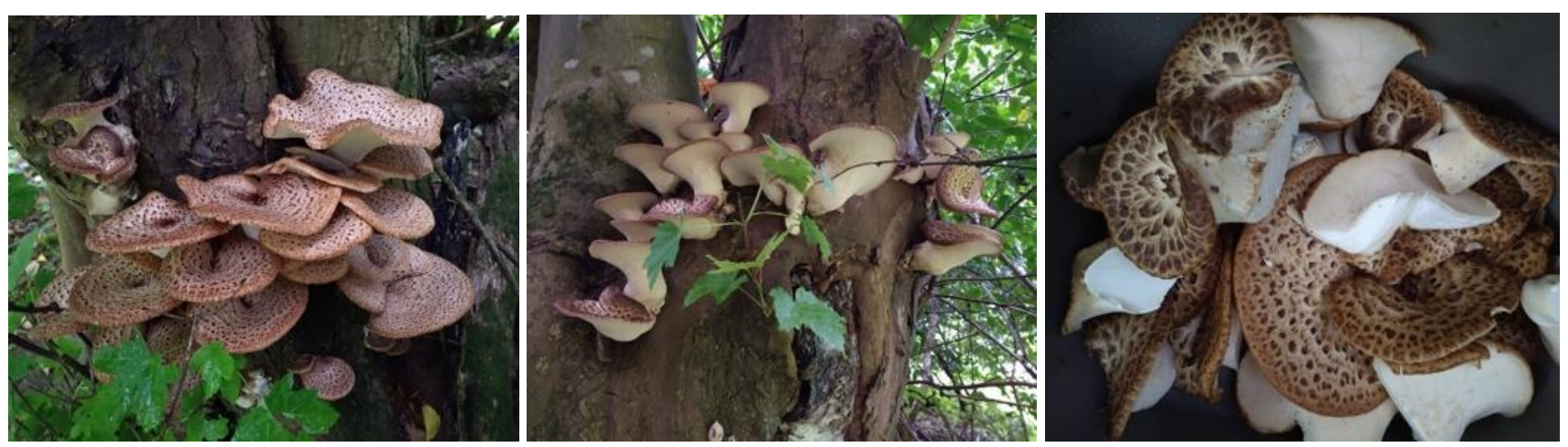

Figure 1. Fruiting bodies of Cerioporus squamosus collected from the Isle of Bute, in Scotland (UK). Photographs were taken by Dr. Paul W Thomas 


\section{Metabolic profile of $C$. squamosus hydromethanolic extract by GC-MS analysis \\ GC-MS analysis of silylated metabolites}

Metabolite analysis was carried out as follows. Briefly, $100 \mathrm{mg}$ of finely powdered C. squamosus was extracted with $5 \mathrm{~mL} \mathrm{100 \%} \mathrm{methanol} \mathrm{with} \mathrm{sonication} \mathrm{for} 30 \mathrm{~min}$ with frequent shaking, followed by centrifugation at $12,000 \times \mathrm{g}$ for $10 \mathrm{~min}$ to remove debris. $100 \mu \mathrm{L}$ of the methanolic extract was aliquoted in screw-cap vials and left to evaporate until complete dryness. For derivatization, 150 $\mu \mathrm{L}$ of $\mathrm{N}$-methyl-N-(trimethylsilyl)-tri fluoroacetamide (MSTFA) that was previously diluted $1: 1 \%$ with an hydrous pyridine added to the dried methanolic extract and incubated at $60^{\circ} \mathrm{C}$ for $45 \mathrm{~min}$ prior to analysis using GCMS (Farag et al. 2018).

\section{GC-MS analysis of C. squamosus extract}

The GC-MS analysis of the extract was conducted as described by Elkhateeb et al. (2019d) using a TRACE GC Ultra Gas Chromatographs (THERMO Scientific Corp., USA), coupled with a thermo mass spectrometer detector (ISQ Single Quadrupole Mass Spectrometer). Helium was used during the analyses as carrier gas at a flow rate of 1.0 $\mathrm{mL} / \mathrm{min}$ and a split ratio of $1: 10$. The program of temperature started with $60^{\circ} \mathrm{C}$ for $1 \mathrm{~min}$; followed by rising temprature at $4.0^{\circ} \mathrm{C} / \mathrm{min}$ to $240{ }^{\circ} \mathrm{C}$ and held for $1 \mathrm{~min}$. The injector and detector were held at $210^{\circ} \mathrm{C}$. Diluted samples $(1: 10$ hexane, $\mathrm{v} / \mathrm{v})$ of $1 \mu \mathrm{l}$ of the mixtures were always injected. After that, mass spectra were measured by electron ionization (EI) at $70 \mathrm{eV}$, under a spectral range of $\mathrm{m} / \mathrm{z} 40-450$.

\section{In vitro wound healing activity of $C$. squamosus hydromethanolic extract}

The wound healing activity of C. squamosus hydromethanolic extract and the migration rates of BJ-1 cells were evaluated in the Bioassay-cell Culture Laboratory, National Research Center, Dokki, Egypt. using the scratch assay method. BJ-1 cell line is human skin fibroblast that is derived from normal foreskin and was obtained from American Type Culture Collection, ATCC® CRL-2522 ${ }^{\mathrm{TM}}$, Manassas, VI, USA)The cell density of $2 \times$ $10^{5}$ cells were seeded into each well of a 24 -well plate and incubated with complete medium at $37^{\circ} \mathrm{C}$ and $5 \% \quad \mathrm{CO}_{2}$. After $24 \mathrm{~h}$ of incubation, the monolayer confluent cells were scrapped horizontally with a sterile P200 pipette tip. The debris was removed by washing with PBS. The cells were treated with $C$. squamosus methanolic extract at concentration 50, 100, $200 \mu \mathrm{g} / \mathrm{mL}$. The cells without treatment were used as negative control. The induced scratch that represented the wound was photographed at $0 \mathrm{~h}$ using phase-contrast microscopy at $\times 40$ magnification, before incubation with the samples. After $24 \mathrm{~h}$ of incubation, the second set of images was photographed. To determine the migration rate, the images were analyzed using "image J" software, and percentage of the closed area was measured and compared with the value obtained at $0 \mathrm{~h}$. An increase in the percentage of the closed area was taken as an indication for the cell migration. Experiments were performed in the triplicate and the data were recorded and analyzed statistically using SPSS 11.

Wound closure $(\%)=\underline{(\text { Measurement at } 0 \mathrm{~h}-\text { Measurement after } 24 \mathrm{~h})} \times 100$ Measurement at $0 \mathrm{~h}$

\section{In vitro anti-skin cancer activity of $C$. squamosus hydromethanolic extract}

The in vitro anti-skin cancer study was performed in the Bioassay-cell culture laboratory, National Research Centre, Dokki, Egypt. Cell viability assay was assessed by the mitochondrial-dependent reduction of yellow MTT (3-(4,5dimethylthiazol-2-yl)-2,5-diphenyl tetrazolium bromide) to reduced purple formazan (Mosmann 1983).

This experiment was conducted under sterile conditions via a Laminar flow cabinet biosafety class II level (Baker, SG403INT, Sanford, ME, USA). In this experiment, A431 cell line was used. A431 is human squamous cell carcinoma, A431 (ACC 91, DSMZ German collection of microorganisms and cell cultures, Braunschweig, Germany). First, skin cancer cells (A431) were suspended in DMEM-F12 medium, together with $1 \%$ antibioticantimycotic mixture $(10,000 \mathrm{U} / \mathrm{mL}$ potassium penicillin, $10,000 \mu \mathrm{g} / \mathrm{mL}$ streptomycin sulfate and $25 \mu \mathrm{g} / \mathrm{mL}$ amphotericin $\mathrm{B}$ ) and $1 \% \mathrm{~L}$-glutamine. The experiment was conducted at $37^{\circ} \mathrm{C}$ under $5 \% \mathrm{CO}_{2}$.

A431 skin cancer cells were batch cultured for 10 days, then at a concentration of $10^{4}$ cells/well they were seeded in a fresh complete growth medium in 96-well microtiter plastic plates under $5 \% \mathrm{CO}_{2}$ at $37{ }^{\circ} \mathrm{C}$ for $24 \mathrm{hr}$ using a water-jacketed carbon dioxide incubator (Sheldon, TC2323, Cornelius, OR, USA). Media was aspirated and then fresh medium (without serum) was added. The cells were incubated either alone (negative control) or with different concentrations of $C$. squamosus hydromethanolic extract with final concentrations of $(12.5,25,50$, and 100 $\mu \mathrm{g} / \mathrm{mL})$. The medium was aspirated after $48 \mathrm{hr}$ of incubation and $40 \mu \mathrm{L}$ MTT salt $(2.5 \mu \mathrm{g} / \mathrm{mL})$ were added to each well. Finally, the plates were incubated for four more hours under the same conditions.

Two hundred $\mu 1$ of $10 \%$ Sodium dodecyl sulfate (SDS) in deionized water was added after the end of incubation to each well then the plate was incubated overnight at $37^{\circ} \mathrm{C}$. Adrinamycin ${ }^{\circledR}$ (Pharmacia India Pvt Ltd. Gurgaon, Haryana 122001, India) was used as a positive control (Thabrew et al. 1997), and medium free of tested extract was used as negative control. Color intensity was measured at $595 \mathrm{~nm}$ using a microplate multi-well reader (Bio-Rad Laboratories Inc., model 3350, Hercules, California, USA) and a reference wavelength of $620 \mathrm{~nm}$. A statistical significance was tested between samples and negative control using independent t-test by SPSS 11 program. The change in viability percentage was calculated as following:

$\left(\left(\mathrm{A}_{\mathrm{s}} / \mathrm{A}_{\mathrm{c}}\right)-1\right) \times 100$

Where;

$\left(A_{s}\right)$ is sample absorbance, and $\left(A_{c}\right)$ is negative control absorbance. $\mathrm{IC}_{50}$ was determined by SPSS 11 program. 


\section{RESULTS AND DISCUSSION}

\section{Metabolic profile identified from $C$. squamosus hydromethanolic extract}

GC-MS analysis performed on the silylated metabolites originating from the hydromethanolic extract of $C$. squamosus fruiting bodies revealed detection of 19 compounds (Figure 2, Table 1). The total peak areas of the detected compounds were $70.76 \%$ and SI $\geq 750$, the probabilities of the structures of the detected compounds are listed in Table 1. The peak area\% representing the sugar alcohol, xylitol, was the major peak (28.59\%), followed by that of palmitic acid (17.43\%), then glycerol (10.94\%). The extract also contained amino acids such as alanine, L-valine, L-isoleucine, L-threonine. Moreover, many organic and fatty acids were detected such as Dlactic acid, oxalic acid, myristic acid, stearic acid, pentadecanoic acid, and dodecanoic acid (lauric acid). The

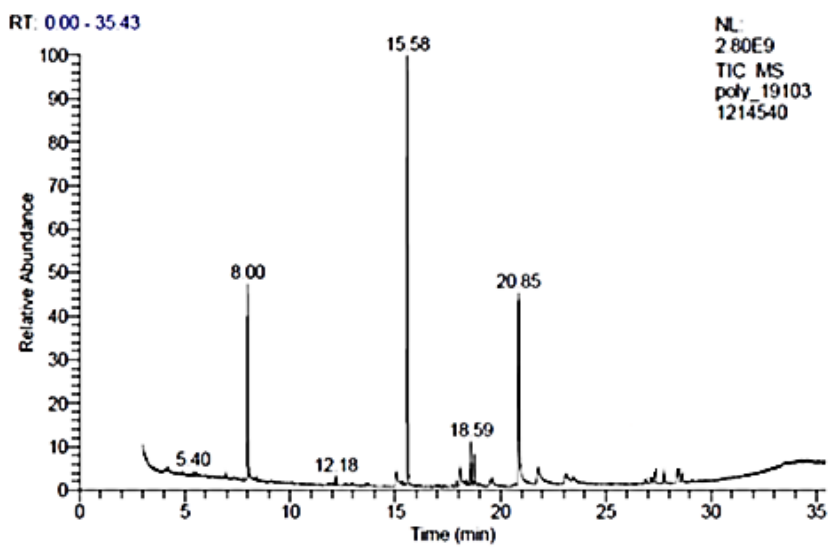

Figure 2. GC-MS chromatogram of the silylated metabolites originated from Cerioporus squamosus hydromethanolic extract sugar alcohols - sorbitol, and erythritol were also identified in small peak areas of 3.01 , and $0.22 \%$, respectively.

In vitro wound healing activity of $C$. squamosus hydromethanolic extract towards human skin fibroblast ((BJ-1) cells

The effect of $C$. squamosus hydromethanolic extract on the migration of fibroblast cells (BJ-1) was investigated because cell migration plays a key role in wound repair and healing. As shown in Figures 3, and 4 after $24 \mathrm{~h}$ of exposure to $C$. squamosus hydromethanolic extract, cells migrated towards the provisional gap induced. Migration analysis values showed that $50 \mu \mathrm{g} / \mathrm{mL}$ of the $C$. squamosus extract was the concentration causing the highest increase in cell migration $(71.7 \%)$. Further increase in extract concentration was accompanied with decrease in migration rate until reached $3.24 \%$ after $24 \mathrm{~h}$ of exposure to a concentration of $200 \mu \mathrm{g} / \mathrm{mL}$ of the mushroom extract.

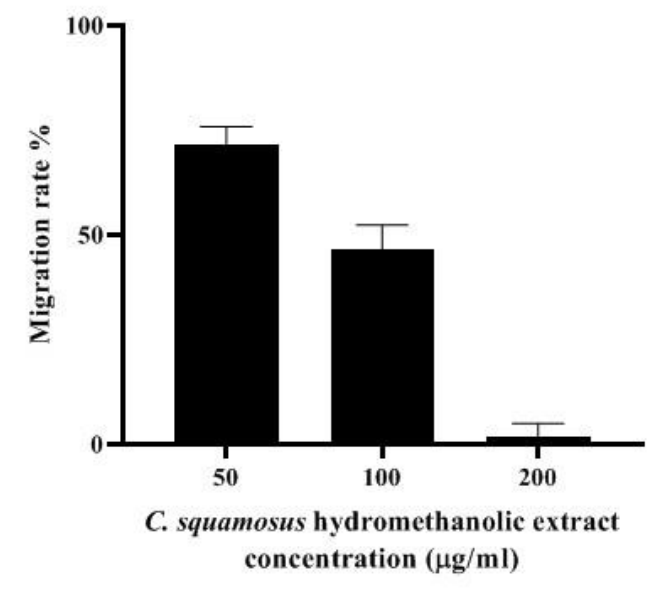

Figure 3. The percentage of migration rate for BJ-1 cells after $24 \mathrm{~h}$ of treatment with Cerioporus squamosus hydromethanolic extract.

Table 1. Identified compounds of silylated Cerioporus squamosus extract using GC-MS

\begin{tabular}{|c|c|c|c|c|c|c|}
\hline No. & RT & Area \% & Compound name & Molecular weight & Molecular formula & SI \\
\hline 1 & 4.89 & 0.24 & Alanine & 89 & $\mathrm{C}_{3} \mathrm{H}_{7} \mathrm{NO}_{2}$ & 860 \\
\hline 2 & 5.40 & 0.30 & Ethanedioic acid (Oxalic acid) & 90 & $\mathrm{C}_{2} \mathrm{H}_{2} \mathrm{O}_{4}$ & 752 \\
\hline 3 & 6.94 & 0.34 & L-Valine & 117 & $\mathrm{C}_{5} \mathrm{H}_{11} \mathrm{NO}_{2}$ & 868 \\
\hline 4 & 8.00 & 10.94 & Glycerol & 92 & $\mathrm{C}_{3} \mathrm{H}_{8} \mathrm{O}_{3}$ & 927 \\
\hline 5 & 8.42 & 0.28 & L-Isoleucine & 131 & $\mathrm{C}_{6} \mathrm{H}_{13} \mathrm{NO}_{2}$ & 880 \\
\hline 6 & 10.10 & 0.24 & L-Threonine & 119 & $\mathrm{C}_{4} \mathrm{H}_{9} \mathrm{NO}_{3}$ & 824 \\
\hline 7 & 12.06 & 0.22 & Erythritol & 122 & $\mathrm{C}_{4} \mathrm{H}_{10} \mathrm{O}_{4}$ & 920 \\
\hline 8 & 12.18 & 0.69 & meso-Erythritol & 122 & $\mathrm{C}_{4} \mathrm{H}_{10} \mathrm{O}_{4}$ & 931 \\
\hline 9 & 13.77 & 0.13 & 2-Deoxyribitol & 136 & $\mathrm{C}_{5} \mathrm{H}_{12} \mathrm{O}$ & 834 \\
\hline 10 & 15.05 & 2.08 & Dodecanoic acid & 200 & $\mathrm{C}_{12} \mathrm{H}_{24} \mathrm{O}_{2}$ & 911 \\
\hline 11 & 15.58 & 28.59 & Xylitol & 152 & C5H12O5 & 927 \\
\hline 12 & 16.88 & 0.33 & D-Psicofuranose & 180 & $\mathrm{C}_{6} \mathrm{H}_{12} \mathrm{O}$ & 850 \\
\hline 13 & 18.08 & 2.07 & Tetradecanoic acid (Myristic acid) & 228 & $\mathrm{C}_{14} \mathrm{H}_{28} \mathrm{O}_{2}$ & 898 \\
\hline 14 & 18.59 & 3.01 & sorbitol (glucitol) & 182 & $\mathrm{C}_{6} \mathrm{H}_{14} \mathrm{O}_{6}$ & 901 \\
\hline 15 & 18.68 & 0.20 & 2,2'-oxybis(ethan-1-ol) & 106 & $\mathrm{C}_{4} \mathrm{H}_{10} \mathrm{O}_{3}$ & 753 \\
\hline 16 & 19.52 & 0.74 & Pentadecanoic acid & 242 & $\mathrm{C}_{15} \mathrm{H}_{30} \mathrm{O}_{2}$ & 740 \\
\hline 17 & 20.85 & 17.43 & Hexadecanoic acid (Palmitic Acid) & 256 & $\mathrm{C}_{16} \mathrm{H}_{32} \mathrm{O}_{2}$ & 866 \\
\hline 18 & 23.10 & 2.34 & 2-hydroxy Propanoic acid (D-lactic acid) & 90 & $\mathrm{C}_{3} \mathrm{H}_{6} \mathrm{O}_{3}$ & 779 \\
\hline 19 & 23.44 & 0.59 & Octadecanoic acid (Stearic Acid) & 284 & $\mathrm{C}_{18} \mathrm{H}_{36} \mathrm{O}_{2}$ & 759 \\
\hline
\end{tabular}




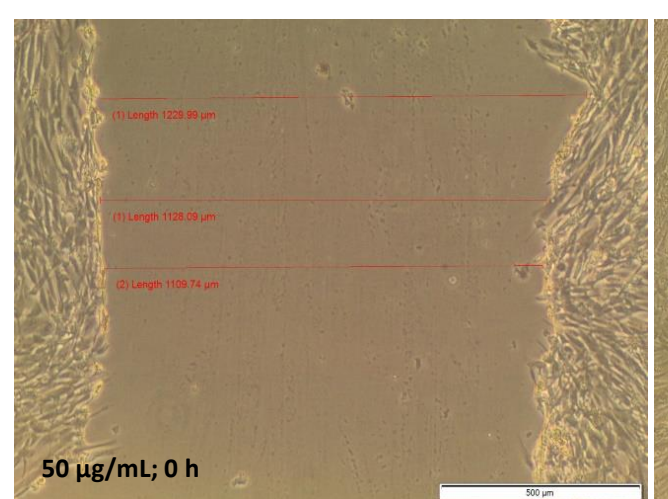

$\mathbf{A}$

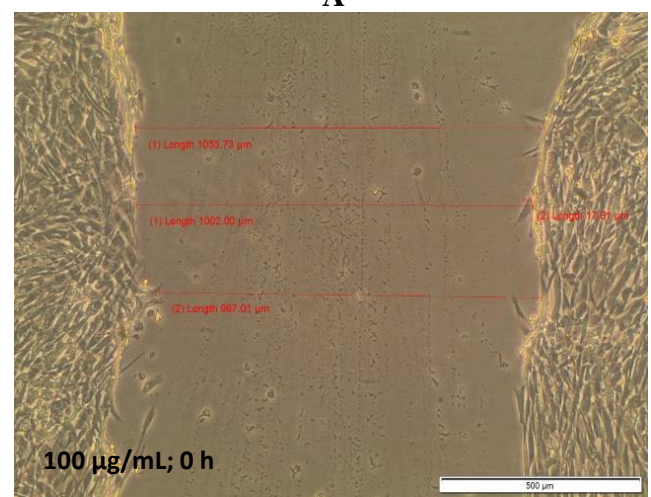

C

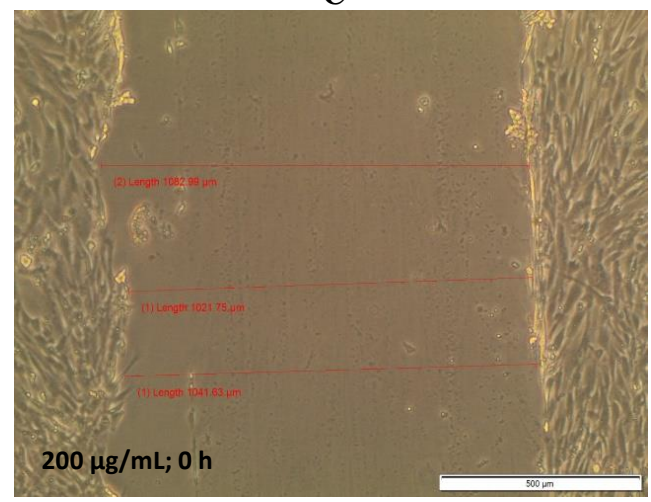

$\mathbf{E}$

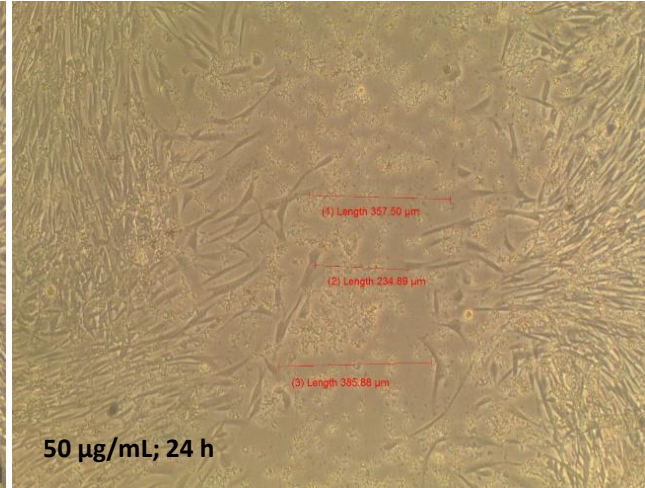

B

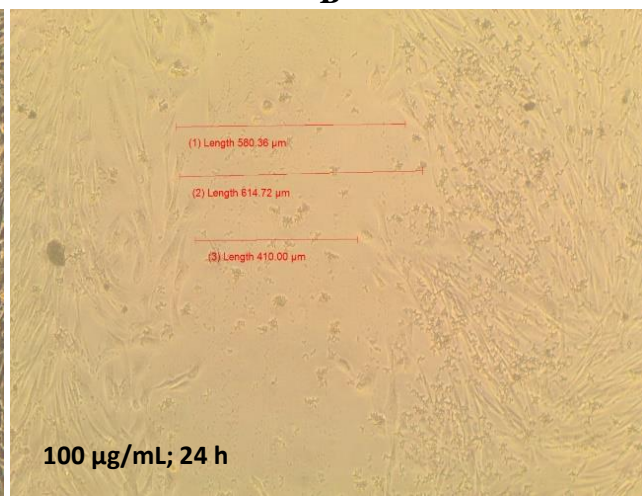

D

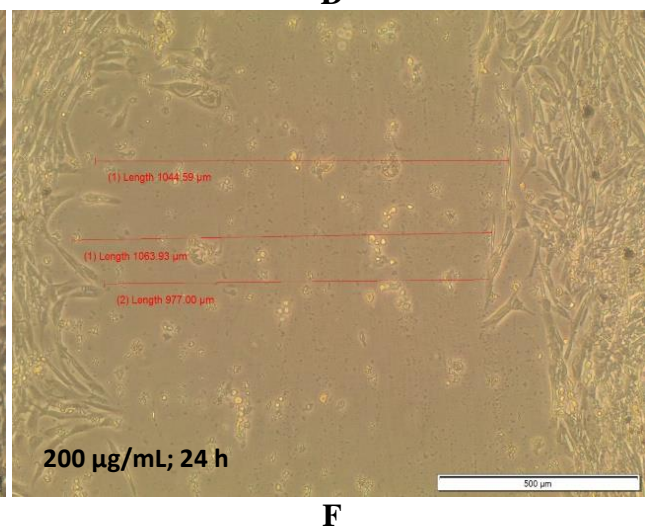

Figure 4. Wound healing ability of Cerioporus squamosus hydromethanolic extraction to BJ-1 cells. Images were acquired at (A) 50 $\mu \mathrm{g} / \mathrm{mL} 0 \mathrm{~h}$, and (B) $50 \mu \mathrm{g} / \mathrm{mL}$ after $24 \mathrm{~h}$ of exposure to extract. (C) $100 \mu \mathrm{g} / \mathrm{mL} 0 \mathrm{~h}$, and (D) $100 \mu \mathrm{g} / \mathrm{mL}$ after $24 \mathrm{~h}$ of exposure to extract. (E) $200 \mu \mathrm{g} / \mathrm{mL} 0 \mathrm{~h}$ and (F) $200 \mu \mathrm{g} / \mathrm{mL}$ after $24 \mathrm{~h}$ of exposure to extract. Images were analyzed using "image J" software, and percentage of the closed area was measured and compared with the value obtained at $0 \mathrm{~h}$

\section{Effect of $C$. squamosus hydromethanolic extract on the viability of A431 human squamous cell carcinoma skin cancer cell line}

The viability or the proliferation of the skin cancer cell line (A431) was tested by the MTT assay (3-(4,5dimethylthiazol-2-yl)-2,5-diphenyltetrazolium bromide). This is a colorimetric assay that measures cell metabolic activity. Here, NAD(P)H-dependent cellular oxidoreductase enzymes, which is an indicator of the cell viability, was measured. The function of this enzyme is to reduce the tetrazolium dye of the MTT which in turn forms an insoluble purple colored formazan that dissolved in acidified alcohol and finally measured at $595 \mathrm{~nm}$.
Using the MTT assay, different concentrations of the $C$. squamosus hydromethanolic extract (12, 25, 50, 100 $\mu \mathrm{g} / \mathrm{mL}$ ) were examined to evaluate their capabilities to inhibit A431 skin cancer cell proliferation. Results shown in Figure 5 revealed the promising effect of the mushroom extract on reducing A431 cell proliferation. This appeared as a gradual decrease in cell viability with the gradual increase of $C$. squamosus hydromethanolic extract concentration (Figure 6). The maximum cell viability reducing ability was obtained using a concentration of 100 $\mu \mathrm{g} / \mathrm{mL}$ recording a cell viability $\%$ of 3.7 , and the $\mathrm{IC}_{50}$ was found to be $52.6 \mu \mathrm{g} / \mathrm{mL}$. 


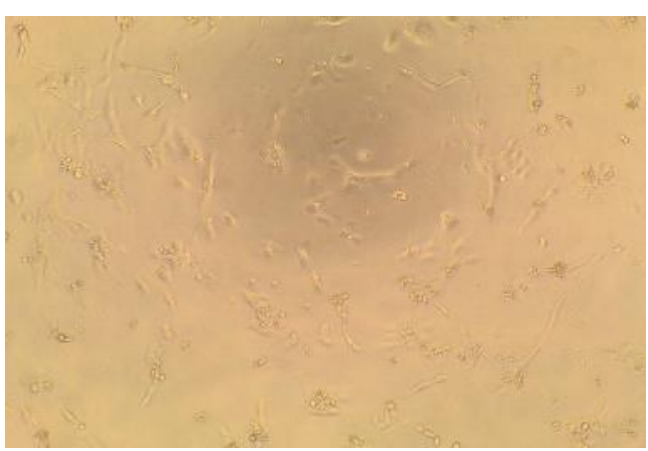

A

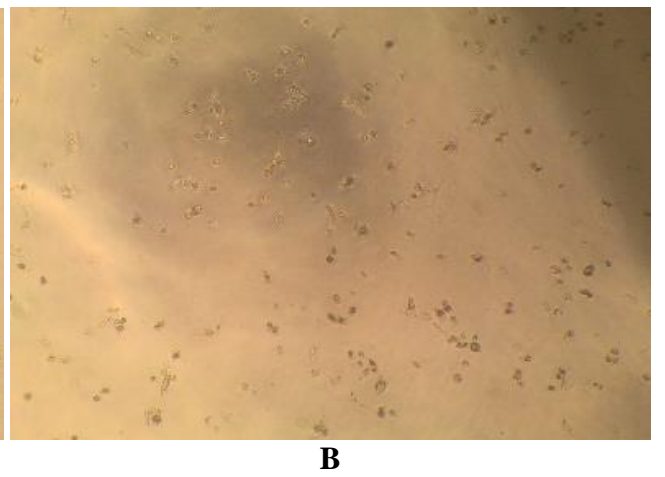

Figure 5.A. A431 skin cancer cell line before treatment with C. squamosus hydromethanolic extract. B. A431 skin cancer cell line after treatment with $100 \mu \mathrm{g} / \mathrm{mL}$ of Cerioporus squamosus hydromethanolic extract for $48 \mathrm{~h}$

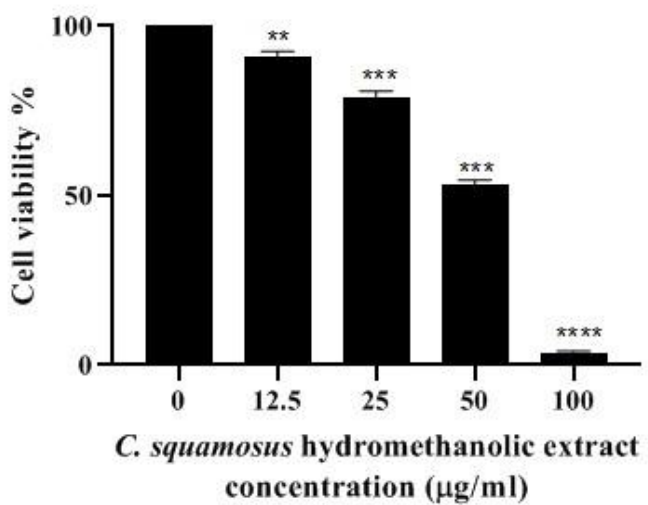

Figure 6. Cerioporus squamosus hydromethanolic extract reduced the proliferation of A431 skin cancer cells. A431 cells were cultured in the presence of $0,12.5,25,50$, and $100 \mu \mathrm{g} / \mathrm{mL}$ of the extract for $48 \mathrm{~h}$ and followed by measuring the cell viability via MTT assay. Error bars represent mean \pm SD where $* p \leq 0.05$; $* * \mathrm{p} \leq 0.01 ; * * * \mathrm{p} \leq 0.001 ; * * * * \mathrm{p} \leq 0.0001$ indicates a significant decrease over $0 \mu \mathrm{g} / \mathrm{mL}$ concentration

\section{Discussion}

Mushrooms are generous sources of metabolites with promising bioactivities. Moreover, being edible encourages further investigation to authorize their application in medicines and pharmaceuticals. Studies on many mushroom species such as Ganoderma lucidum, Cordyceps militaris, Hericium erinaceus, Metacordyceps neogunnii (Synonym of Keithomyces neogunnii), and Dictyophora indusiata revealed their potent in vitro biological capabilities as anticoagulant, antiviral, hypocholesterolemic, anti-colon cancer, and antioxidant agents (Elkhateeb et al. 2019b; Elkhateeb et al. 2019c; El-Hagrassi et al. 2020; Daba et al. 2020). Furthermore, some mushrooms have promising wound healing activities (Buko et al. 2019; Elkhateeb et al. 2019c; Kosanić et al. 2020). Cerioporus squamosus is an edible, basidiomycetous mushroom that is rich in macronutrients, organic acids, fatty acids and other important compounds (Elkhateeb et al. 2019a). Additionally, C. squamosus has been used as medicine for its diuretic, antimicrobial, cytotoxic, immuno-enhancing, anti-inflammatory, hepatoprotective, nephroprotective, antioxidant activities, and stimulate hair growth (Doskocil et al. 2016; Fernandes et al. 2016; Elkhateeb et al. 2019a).

Understanding the effects of $C$. squamosus extract on mammalian cells is required, to provide the basis for the development of a novel and safe product useful for treatment of various diseases. In this study, the wound healing, and anti-human skin cancer activities of the hydromethanolic extract of $C$. squamosus were investigated. Moreover, chemical analysis was performed on the hydromethanolic $C$. squamosus methanolic extract in order to detect its bioactive metabolites.

The in vitro evaluation of the anticancer activity of $C$. squamosus hydromethanolic extract against epidermoid carcinoma A431 cell line revealed its promising anticancer effect, which showed its optimum action after treatment with extract at concentration of $100 \mu \mathrm{g} / \mathrm{mL}$ where the cell viability was $3.7 \%$.

It is important to mention that the current work represents the first study investigating the effect of $C$. squamosus hydromethanolic extract on human skin cancer cell lines. As shown from the GC-Ms analysis of the sialylated metabolites originated from C. squamosus extract, 19 compounds were detected and listed in table 1. More than quarter of the area percentage of the total detected metabolites $(28.59 \%)$ was occupied by xylitol sugar alcohol. Xylitol has various biological activities and is used most commonly in oral hygiene products due to its anti-inflammatory and anticaries characteristics (Nayak et al. 2014). Many in vitro studies on cancer cell lines have elucidated the dose-dependent inhibitory role of xylitol on cell proliferation, which is suggested to be achieved through autophagy (Park et al. 2015).

Moreover, a recent study had suggested that partial substitution of glucose with sugar alcohols especially xylitol could deeply suppress proliferation of oral cancer but not non-transformed cells (Trachootham et al. 2017). One of the highly detected metabolites in $C$. squamosus hydromethanolic extract is palmitic acid (representing 17.43 area \%). Long-chain fatty acids, such as palmitic acid, were testified in many studies to have cytotoxic and antiproliferative activities against cancer cells by inhibiting DNA topoisomerase I and inducing 
apoptosis in human leukemic cells (Harada et al. 2002; Ravi and Krishnan 2017). Glycerol, which is also detected in C. squamosus extract (10.94\%), has inhibitory effects on growth and invasion of some human cancer cell lines (Sakurai et al. 2011). Interestingly, the majority of remaining compounds detected in the hydromethanolic extract of $C$. squamosus have also been reported to have anti-cancer properties. Sorbitol has anticancer activities against several tumor models (Lu et al. 2014) through inducing apoptosis in an efficient and rapid way when provided at high concentrations as a part of hyperosmotic stress mechanisms (Marfè et al. 2008). Sorbitol was reported in many studies for its ability to activate the p38 MAPK signal transduction pathway and induce the apoptosis of tumor cells (Marfè et al. 2008). Additionally, the medium-chain length fatty acid, dodecanoic acid, which is known also as lauric acid has well reported anticancer activity (Sandhya et al. 2016). In previous in vitro studies, lauric acid has induced apoptosis in colon cancer cells due to oxidative stress (Fauser et al. 2013). Also, lauric acid has induced cell death in colon cancer cells settled by the epidermal growth factor receptor down-regulation (Sheela et al. 2019).

Generally, the overall pattern obtained after many in vitro studies on different cell lines revealed that even the lauric acid-containing derivatives were the most effective anticancer agent (Chhikara et al. 2011). On the other hand, several studies have suggested that selective amino acid deprivation of serine and glycine or phenylalanine and tyrosine can inhibit tumor growth in animal models (Maddocks et al. 2017). Alanine and glutamic acid-induced apoptosis of gastric cancer cells (Gu et al. 2015), $\beta$-alanine exhibited a co-therapeutic activity in the treatment of breast tumors and reduced cancerous metabolism besides reducing extracellular acidification which leads to suppressed aggressiveness. Also, $\beta$-alanine increased the efficacy of Dox on MCF-7 cells at low concentrations (Vaughan et al. 2014). Oxalic acid, which was also one of the metabolites detected in the extract, has been reported for its therapeutic effect for controlling, and treating, neoplasia, tumors, including brain tumors, and for preventing the new growth of different or abnormal tissues (Hart et al. 2000). However, it should be noted that some studies have reported the ability of oxalate to induce breast cancer when injected into mice mammary fat pad (Castellaro et al. 2015).

It is worth noting that cancer patients (including skin cancer patients ) are subjected to various physiological changes including the process of the disease itself, treatment course, social situation as well as poor nutritional status and in combination, these factors may contribute to delay of wound healing processes (Payne et al. 2008).

Wound healing is an important biological mechanism that occurs in the human body and includes the wellregulated steps; hemostasis, inflammation, proliferation, and finally remodelling (Guo and DiPietro 2010). Several factors can interfere with one or more of these process steps resulting in impaired or delayed wound healing, such as diabetes mellitus, hypertension, venous stasis disease, cancer disease as well as some treatments, age-related health issues, and nutritional status (Menke et al. 2007).

A 2018 analysis of Medicare beneficiaries in the USA reported about 8.2 million (14.5\%) suffered from wounds including both infected and non-infected (By microorganisms). Moreover, the Medicare cost estimated for curing these wounds ranged from $\$ 28.1$ billion to $\$ 96.8$ billion. It is expected that the annual cost for medical products for wound care alone, could reach \$15-22 billion by 2024 (Sen 2019). Hence, its crucial to find new low-cost wound treatments primarily originating from natural sources with low toxicity and minimal side effects.

Nowadays, the interest of many scientists has been directed to phytomedicine due to the demonstrated ability of many plants to aid in the healing of wounds. However, little is known about the wound healing properties of mushrooms to heal wounds (Elkhateeb et al. 2019c). So, we were interested to evaluate the ability of $C$. squamosus mushrooms to treat wounds via the scratch assay in order to develop a natural product that promotes wound healing in cancer patients and specifically "skin cancer patients". The results showed that promising anti-skin cancer effect, especially helpful to the cancer patients suffering from delayed and impaired wound healing.

The effect of $C$. squamosus hydromethanolic extract on the migration of BJ-1 normal human fibroblast cells was tested, where different concentrations of C. squamosus hydromethanolic extract (ranging from 50-200 $\mu \mathrm{g} / \mathrm{mL}$ ) were added to $\mathrm{BJ} 1$ monolayer confluent cells and it was found that the extract exhibits an obvious effect on wound healing where the migration rate at the concentration of 50 $\mu \mathrm{g} / \mathrm{mL}$ was $71.7 \%$. However, any further increase in the extract concentration (beyond $50 \mu \mathrm{g} / \mathrm{mL}$ ) was accompanied by gradual decrease in migration rate until it reached the level of $3.24 \%$ at the concentration of $200 \mu \mathrm{g} / \mathrm{mL}$ after 24 hours of incubation. As the lowest tested concentration displayed the highest migration rate, it remains possible that the optimal concentration level may be below 50 $\mu \mathrm{g} / \mathrm{mL}$ and further investigation will be needed to identify this optimum.

The results obtained from GC-MS may help explain these results. The obtained profile of the analyzed hydromethanolic extract contains 19 compounds that are classified into different groups. They are mainly amino acids, sugar alcohols, fatty acids, and carbohydrates (see table 1). Lately, some studies have focused on examining the roles of various immune nutrients such as amino acids, fatty acids, and minerals on wound healing (Silva et al. 2018).

Our results showed the presence of four amino acids: alanine, L-valine, L-isoleucine, and L-threonine. Many of amino acids play a vital role in building and repairing human body tissues and are therefore pivotal in wound healing. The human body can create some of these amino acids but not all of them and the deficit must be supplied from foods (Council 1989).

Arginine (detected in C. squamosus extract) is well known for its great role in wound healing. Arginine accelerates insulin secretion, promotes protein regeneration, and helps transport amino acids into the cells. 
It is worth mentioning that $32 \%$ of arginine is nitrogen and it is the only producer of nitric oxide. Nitric oxide is an important role in wound healing as it increases blood flow and oxygen supply to the wound and also increasing collagen formation (Williams et al. 2002) and limiting the inflammation process. Being an edible mushroom, $C$. squamosus could be very helpful in wound healing. Moreover, some studies showed that L-valine, Lisoleucine, and L-threonine also promote the wound healing process and these are also amino acids that cannot be produced by the human body. Branched amino acids such as L-valine and L-isoleucine are crucial in building muscles and hence wound healing, and these two amino acids are different than others in that they are metabolized in the muscle and not in the liver (Stengler 2010). Amino acids are found in different forms, however, the optimum form utilized by the human body is the L-form (Stengler 2010), which is the principal form present in C. squamosus extract and further supports the conclusion that the present extract is a very promising aid to wound healing.

Several fatty acids were also detected in the $C$. squamosus extract. Fatty acids are generally classified on the basis of the presence of double bonds into saturated (no double bonds) and unsaturated (with double bonds) fatty acids (Calder 2011; Silva et al. 2018). Some fatty acids may have a role in healing processes. In a previous study, treatment of a Zebrafish (Danio rerio) model with linoleic acid containing lucuma nut oil, accelerated cell regeneration. This may be attributed to increasing angiogenesis, resuming the oxygen and nutrient supply which in turn promotes wound healing (Silva et al. 2018). Taken together, our results showed that C. squamosus could be a promising treatment with dual action for skin cancer patients who suffer from impaired wound healing, thus limiting the viability of skin cancer cells as well as triggering normal cells to heal.

Having a multi-functional natural source of bioactive compounds is a property of high demand. Especially so, if this source is already an edible one with a history of use by people for its nutritional and medical capabilities. $C$. squamosus hydromethanolic extract has shown promising in vitro skin-related bioactivities with potent anti-skin cancer and wound healing abilities. Results presented in this study encourage further investigation in order to evaluate the in vivo potentials of this extract. As far as we know, this is the first study that describes a significant impact on human skin cancer activity by $C$. squamosus hydromethanolic extract. Moreover, this work represents a significant step toward evaluating the real therapeutic potential of the edible mushroom C. squamosus.

\section{REFERENCES}

Bainbridge P. 2013. Wound healing and the role of fibroblasts. J Wound Care 22 (8): 407-408, 410-412. DOI: 10.12968/jowc.2013.22.8.407.

Blagodatski A, Yatsunskaya M, Mikhailova V, Tiasto V, Kagansky A, Katanaev VL. 2018. Medicinal mushrooms as an attractive new source of natural compounds for future cancer therapy. Oncotarget 9 (49): 29259-29274. DOI: 10.18632/oncotarget.25660.

Buko V, Bakunovich A, Astrowski A, Moroz V, Puchkova T, Kastsianevich A, Tomulewicz M. 2019. Polysaccharides of mushroom Phallus impudicus mycelium: Immunomodulating and wound healing properties. Modern Food Sci Technol 35: 30-37.

Bolla SR, Al-Subaie AM, Al-Jindan RY, Balakrishna JP, Ravi PK, Veeraraghavan VP, Pillai AA, Gollapalli SSR, Joseph JP, Surapaneni KM. 2019. In vitro wound healing potency of methanolic leaf extract of Aristolochia saccata is possibly mediated by its stimulatory effect on collagen-1 expression. Heliyon 5 (5): e01648. DOI: 10.1016/j.heliyon.2019.e01648

Calder PC. 2011. Fatty acids and inflammation: The cutting edge between food and pharma. Eur J Pharmacol 668 (1): S50-S58. DOI: 10.1016/j.ejphar.2011.05.085

Phillips R. 2013. Mushrooms: A comprehensive guide to mushroom, identification. Macmillan publisher limited, Oxford, UK.

Castellaro AM, Tonda A, Cejas HH, Ferreyra H, Caputto BL, Pucci OA, Gil GA. 2015. Oxalate induces breast cancer. BMC Cancer 15: 761. DOI: $10.1186 / \mathrm{s} 12885-015-1747-2$.

Chhikara BS, Jean NS, Mandal D, Kumar A, Parang K. 2011. Fatty acyl amide derivatives of doxorubicin: Synthesis and in vitro anticancer activities. Eur J Med Chem 46 (6): 2037-2042. DOI: 10.1016/j.ejmech.2011.02.056

Chinembiri TN, Du Plessis LH, Gerber M, Hamman JH, Du Plessis J. 2014. Review of natural compounds for potential skin cancer $\begin{array}{llll}\text { treatment. Molecules } \quad 19 & (8): & 11679-11721 . & \text { DOI: }\end{array}$ 10.3390/molecules190811679

Council NR. 1989. Recommended dietary allowances $\left(10^{\text {th }}\right.$ Edition). National Research Council (US) Subcommittee on the Tenth Edition of the Recommended Dietary Allowances. National Academies Press, Washington, USA.

Daba GM, Elkhateeb W, Negm EL-Dien A, Ahmed EF, El-Hagrasi AM, Fayad W, Wen TC. 2020. Therapeutic potentials of $n$-hexane extracts of the three medicinal mushrooms regarding their anti-colon cancer, antioxidant, and hypocholesterolemic capabilities. Biodiversitas 21 (6): 2437-2445. DOI: $10.13057 /$ biodiv/d210615

Doskocil I, Havlik J, Verlotta R, Tauchen J, Vesela L, Macakova K, Rada V. 2016. In vitro immunomodulatory activity, cytotoxicity and chemistry of some central European polypores. Pharm Biol 54 (11): 2369-2376. DOI: 10.3109/13880209.2016.1156708

El-Hagrassi A, Daba G, Elkateeb W, Ahmed E, Negm El Dien A, Fayad W, Shaheen M, Shehata R, El-Manawaty M, Wen TC. 2020. In vitro bioactive potential and chemical analysis of the n-hexane extract of the medicinal mushroom, Cordyceps militaris. Malays J Microbiol 16: 40-48.

Elkhateeb W, A, Daba GM, Elnahas MO, Thomas PW. 2019a. Fomes fomentarius and Polyporus squamosus models of marvel medicinal mushrooms. Egypt Pharm J 18: 285-289.

Elkhateeb W, El-Sayed H, Fayad W, Al Kolaibe AG, Emam M, Daba G. 2020. In vitro Anti-breast cancer and antifungal Bio-efficiency of some microalgal extracts. Egypt J Aquat Biol Fish 24: 263-279.

Elkhateeb WA, Daba GM, Elnahas MO, Thomas PW. 2019 b. Anticoagulant Capacities of Some Medicinal Mushrooms. ARC J Pharma Sci 5: 12-16.

Elkhateeb WA, Daba GM, Sheir D, El-Dein AN, Fayad W, Elmahdy EM, Shaheen MN, Thomas PW, Wen TC. 2019d. GC-MS analysis and invitro hypocholesterolemic, anti-rotavirus, anti-human colon carcinoma activities of the crude extract of a Japanese Ganoderma spp. Egypt Pharma J 18: 102-110.

Elkhateeb WA, Elnahas MO, Thomas PW, Daba GM. 2019c. To heal or not to heal? Medicinal mushrooms wound healing capacities. ARC J Pharma Sci 5: 28-35.

Farag MA, Mohsen E, El-Gendy ANGS. 2018. Sensory metabolites profiling in Myristica fragrans (Nutmeg) organs and in response to roasting as analyzed via chemometric tools. LWT 97: 684-692. DOI: 10.1016/j.lwt.2018.08.002

Fauser JK, Matthews GM, Cummins AG, Howarth GS. 2013. Induction of apoptosis by the medium-chain length fatty acid lauric acid in colon cancer cells due to induction of oxidative stress. Chemotherapy 59 (3): 214-224. DOI: 10.1159/000356067

Fernandes Â, Petrović J, Stojković D, Barros L, Glamočlija J, Soković M, Martins A, Ferreira ICFR. 2016. Polyporus squamosus (Huds.) Fr from different origins: Chemical characterization, screening of the bioactive properties and specific antimicrobial effects against Pseudomonas aeruginosa. LWT-Food Sci Technol 69: 91-97. DOI: 10.1016/j.lwt.2016.01.037

Gu Y, Chen T, Fu S, Sun X, Wang L, Wang J, Lu Y, Ding S, Ruan G, Teng L, Wang M. 2015. Perioperative dynamics and significance of 
amino acid profiles in patients with cancer. J Transl Med 13: 35. DOI: 10.1186/s12967-015-0408-1

Guo S, DiPietro LA. 2010. Factors affecting wound healing. J Dent Res 89 (3): 219-229. DOI: $10.1177 / 0022034509359125$.

Gupta A, Kirar V, Keshri GK, Gola S, Yadav A, Negi PS, Misra K. 2014 Wound healing activity of an aqueous extract of the Lingzhi or Reishi medicinal mushroom Ganoderma lucidum (Higher Basidiomycetes). Int J Med Mushrooms 16: 345-354.

Harada H, Yamashita U, Kurihara H, Fukushi E, Kawabata J, Kamei Y. 2002. Antitumor activity of palmitic acid found as a selective cytotoxic substance in a marine red alga. Anticancer Res 22: 25872590.

Harhaji LJ, Mijatović S, Maksimović-Ivanić D, Stojanović I, Momčilović M, Maksimović V, Tufegdžić S, Marjanović Ž, Mostarica-Stojković M, Vučinić Ž, Stošić-Grujičić S. 2008. Anti-tumor effect of Coriolus versicolor methanol extract against mouse B16 melanoma cells: in vitro and in vivo study. Food Chem Toxicol 46 (5): 1825-1833. DOI: 10.1016/j.fct.2008.01.027

Harhaji Trajković LM, Mijatović SA, Maksimović-Ivanić DD, Stojanović ID, Momčilović MB, Tufegdžić SJ, Maksimović VM, Marjanovi ŽS, Stošić-Grujičić SD. 2009. Anticancer properties of Ganoderma lucidum methanol extracts in vitro and in vivo. Nutr Cancer 61: 696707. DOI: $10.1080 / 01635580902898743$

Hart FJ. 2000. Oxalic acid or oxalate composition and method of treatment. U.S. Patent 6133317A, available at https://patents.google.com/patent/US6133317A, accessed on 31.08.2020.

Ivanova TS, Krupodorova TA, Barshteyn VY, Artamonova AB, Shlyakhovenko VA. 2014. Anticancer substances of mushroom origin. Exp Oncol 36: 58-66.

James WD, Elston D, Berger, T. 2011. Andrew's Diseases of the Skin EBook: Clinical Dermatology, $11^{\text {th }}$ Edition. Saunders, Elsevier, USA.

Kosanić MM, Šeklić DS, Jovanović MM, Petrović NN, Marković SD 2020. Hygrophorus eburneus, edible mushroom, a promising natural bioactive agent. EXCLI J 19: 442-457. DOI: 10.17179/excli20192056

Kumarasamyraja D, Jeganathan N, Manavalan R. 2012. A review on medicinal plants with potential wound healing activity. Int J Pharm Pharm Sci 2: 101-107.

Lu X, Li C, Wang YK, Jiang K, Gai XD. 2014. Sorbitol induces apoptosis of human colorectal cancer cells via p38 MAPK signal $\begin{array}{lllll}\text { transduction. Oncol Lett } 7 & \text { (6): 1992-1996. DOI: }\end{array}$ 10.3892/ol.2014.1994

Maddocks ODK, Athineos D, Cheung EC, Lee P, Zhang T, van den Broek NJF, Mackay GM, Labuschagne CF, Gay D, Kruiswijk F, Blagih J, Vincent DF, Campbell KJ, Ceteci F, Sansom OJ, Blyth K, Voudsen KH. 2017. Modulating the therapeutic response of tumours to dietary serine and glycine starvation. Nature 544 (7650): 372-376. DOI: 10.1038/nature22056

Marfè G, Morgante E, Di Stefano C, Di Renzo L, De Martino L, Iovane G, Russo MA, Sinibaldi-Salimei P. 2008. Sorbitol-induced apoptosis of human leukemia is mediated by caspase activation and cytochrome c release. Arch Toxicol 82 (6): 371-377. DOI: 10.1007/s00204-007$0261-y$

Menke NB, Ward KR, Witten TM, Bonchev DG, Diegelmann RF. 2007. Impaired wound healing. Clin Dermatol 25 (1): 19-25. DOI: 10.1016/j.clindermatol.2006.12.005

Mocan A, Fernandes Â, Barros L, Crişan G, Smiljković M, Soković M, Ferreira ICFR. 2018. Chemical composition and bioactive properties of the wild mushroom Polyporus squamosus (Huds.) Fr: A study with samples from Romania. Food Funct 9 (1): 160-170. DOI: $10.1039 / \mathrm{c} 7 \mathrm{fo} 01514 \mathrm{c}$
Mosmann T. 1983. Rapid colorimetric assay for cellular growth and survival: Application to proliferation and cytotoxicity assays. J Immunol Methods 65 (1-2): 55-63. DOI: 10.1016/00221759(83)90303-4

Nayak PA, Nayak UA, Khandelwal V. 2014. The effect of xylitol on dental caries and oral flora. Clin Cosmet Investig Dent 6: 89-94. DOI: $10.2147 / C C I D E . S 55761$

Park E, Park MH, Na HS, Chung J. 2015. Xylitol induces cell death in lung cancer A549 cells by autophagy. Biotechnol Lett 37: 983-990. DOI: $10.1007 / \mathrm{s} 10529-014-1757-1$

Payne WG, Naidu DK, Wheeler CK, Barkoe D, Mentis M, Salas RE, Smith Jr DJ, Robson MC. 2008. Wound healing in patients with cancer. Eplasty 8: 68-90.

Ravi L, Krishnan K. 2017. Cytotoxic potential of N-hexadecanoic acid extracted from Kigelia pinnata leaves. Asian J Cell Biol 12: 20-27.

Ray R, Pal A, Paul S. 2020. Assessment of the impact of wild stinkhorn mushroom extracts on different cancer cell proliferation and study of primary metabolites. Phcog J 12: 699-708.

Sakurai S, Okada Y, Mataga I. 2011. Inhibitory effects of glycerol on growth and invasion of human oral cancer cell lines. J Hard Tissue Biol 20: 37-46.

Sandhya S, Talukdar J, Bhaishya D. 2016. Chemical and biological properties of lauric acid: A review. Int J Adv Res 4: 1123-1128.

Sen CK. 2019. Human wounds and its burden: an updated compendium of estimates. Adv Wound Care (New Rochelle) 8 (2): 39-48. DOI: 10.1089/wound.2019.0946

Sheela DL, Narayanankutty A, Nazeem PA, Raghavamenon AC, Muthangaparambil SR. 2019. Lauric acid induces cell death in colon cancer cells mediated by the epidermal growth factor receptor downregulation: An in silico and in vitro study. Hum Exp Toxicol 38 (7): 753-761. DOI: $10.1177 / 0960327119839185$

Silva JR, Burger B, Kühl CMC, Candreva T, dos Anjos MBP, Rodrigues HG. 2018. Wound healing and omega-6 fatty acids: From inflammation to repair. Mediators Inflamm 2018: 2503950. DOI: $10.1155 / 2018 / 2503950$

Stengler M. 2010. The Natural Physician's Healing Therapies: Proven Remedies Medical Doctors Don't Know, Penguin, Canada.

Thabrew MI, Hughes RD, Mcfarlane IG. 1997. Screening of hepatoprotective plant components using a HepG2 cell cytotoxicity assay. J Pharm Pharmacol 49 (11): 1132-1135. DOI: 10.1111/j.20427158.1997.tb06055.x

Trachootham D, Chingsuwanrote P, Yoosadiang P, Mekkriangkrai D, Ratchawong T, Buraphacheep N, Kijanukul S, Saekhow S, Pongpitchayadej O, Vongvachvasin K, Sittikornpaiboon P, Tuntipopopat S. 2017. Partial substitution of glucose with xylitol suppressed the glycolysis and selectively inhibited the proliferation of oral cancer cells. Nutr Cancer 69 (6): 862-872. DOI: 10.1080/01635581.2017.1339097

Vaughan RA, Gannon NP, Garcia-Smith R, Licon-Munoz Y, Barberena MA, Bisoffi M. Trujillo KA. 2014. $\beta$-alanine suppresses malignant breast epithelial cell aggressiveness through alterations in metabolism and cellular acidity in vitro. Mol Cancer 13: 14. DOI: 10.1186/14764598-13-14

Williams JZ, Abumrad N, Barbul A. 2002. Effect of a specialized amino acid mixture on human collagen deposition. Ann Surg 236 (3): 369375. DOI: $10.1097 / 00000658-200209000-00013$

World Health Organization, Fact sheet: Cancer. 2018. WHO: Geneva, Switzerland. https://www.who.int/news-room/factsheets/detail/cancer. [12 September 2018].

Zhao YY. 2013. Traditional uses, phytochemistry, pharmacology, pharmacokinetics and quality control of Polyporus umbellatus (Pers.) Fries: A review. J Ethnopharmacol 149 (1): 35-48. DOI: 10.1016/j.jep.2013.06.031. 